\title{
Maxims on Miss Teen USA Finalists’ Answers
}

\author{
Petani Bin Mohd Noor, Dato’ Ahmad Maher Secondary School
}

\begin{abstract}
In beauty pageants, the final question segment is undoubtedly the most intense moment for many contestants. This is the round of competition that ultimately detemines their faith, either they make it or break it. The ladies would have to demonstrate their ability to answer a thought provoking final question. It sounds simple but it is easier said than done, expecially when the whole country is watching "live". A study was carried out to investigate maxims in each contestant's answer. The significance is that, when we know the patterns of maxims used, we will be able to help those who would like to become beauty queens to answer correctly. The study involved 15 finalists in Miss Teen USA beauty pageant contests from the years of 2005, 2006, and 2007. All video clips were taken from YouTube. The results showed that $78 \%$ of the contestants observed the maxims, $20 \%$ flouted the maxims and only $2 \%$ infringed the maxims. This showed that, in order to win the crown, many contestants had observed all the four maxims related to Paul Grice's cooperative principle theory.
\end{abstract}

Keywords: beauty pageant finalist's answer; cooperative principle theory; maxims; miss teen USA

\section{Introduction}

In this paper, we look at what American philosopher-linguist Paul Grice (1975) says. He claims that speakers and hearers operate under the cooperative principle which means, both speaker and hearer converse with good intentions. In other words, the speaker utters words and phrases in order to deliver a message to the hearer, who interprets a meaning with the knowledge that there is a message behind the utterance. In order to show what goes on in conversation, Grice introduces four conversational maxims. A speaker might fail to observe a maxim but still get the intended meaning through to the hearer. Failing to observe a maxim is often referred to as "breaking a maxim".

In particular, this study would like to determine what made a beauty queen's answer successful. Did she observe all maxims to win or did she observe non-observance maxims to win or did she use the combination of both to win? Our inference was that, a beauty queen had to observe all maxims in order to win the crown. The failure to respond correctly might make her lose the title. On top of that, this study inferred that a beauty queen's answer would not have any non-observance maxims since breaking a maxim would probably mean that she tried to deceive or put herself away from the chances to hold the title.

It is with anticipation that this research could become an inaugural study of maxims related to answers given by contestants in beauty pageants. This is because, we could probably find a pattern of maxims posed by beauty pageants' winners. Apart from that, it also can be seen as a resource to prospective beauty queen wannabes to prepare themselves for question-answer segments in beauty pageant contests.

\section{Data collection and procedure}

This study used the cooperative principle by Paul Grice (1975). It says that both speaker and hearer converse with the willingness to deliver and interpret a message. The speaker and hearer cooperate and that is why they communicate efficiently (Thomas, 1995). The cooperative principle can be illustrated as follows: 
Table 1: The cooperative principle by Paul Grice (1975)

\begin{tabular}{|c|c|c|c|}
\hline & $\begin{array}{c}\text { Observance/ } \\
\text { Non-Observance }\end{array}$ & Types & Meaning \\
\hline 1 & \multirow[t]{4}{*}{ Observance of Maxims } & $\begin{array}{l}\text { Maxim of } \\
\text { Quantity }\end{array}$ & $\begin{array}{l}\text { The maxim of quantity requires the } \\
\text { speaker to give the right amount of } \\
\text { information when she/ he speaks, which } \\
\text { means not to be too brief or to give more } \\
\text { information than the situation requires. }\end{array}$ \\
\hline & & Maxim of Quality & $\begin{array}{l}\text { The maxim of quality is a matter of } \\
\text { giving the right information. The speaker } \\
\text { says nothing that she/ he knows to be } \\
\text { false or for which she/ he lacks sufficient } \\
\text { evidence. }\end{array}$ \\
\hline & & $\begin{array}{l}\text { Maxim of } \\
\text { Relevance }\end{array}$ & $\begin{array}{l}\text { The maxim of relevance requires the } \\
\text { speaker to be relevant to the context and } \\
\text { situation in which the utterance occurs. }\end{array}$ \\
\hline & & Maxim of Manner & $\begin{array}{l}\text { The maxim of manner is a matter of being } \\
\text { clear and orderly when conversing. The } \\
\text { speaker describes things in order in } \\
\text { which they occur and avoids ambiguity } \\
\text { and obscurity. }\end{array}$ \\
\hline \multirow[t]{5}{*}{2} & \multirow[t]{5}{*}{$\begin{array}{c}\text { Non-Observance of } \\
\text { Maxims }\end{array}$} & Flouting & $\begin{array}{l}\text { When flouting a maxim, the speaker does } \\
\text { not intend to mislead the hearer but wants } \\
\text { the hearer to look for the conversational } \\
\text { implicature, that is, the meaning of the } \\
\text { utterance is not directly stated in the } \\
\text { words uttered. }\end{array}$ \\
\hline & & Violating & $\begin{array}{l}\text { In contrast to flouting, when violating a } \\
\text { maxim, the speaker intends to mislead } \\
\text { the hearer. The speaker speaks the truth } \\
\text { but implies what is false. }\end{array}$ \\
\hline & & Opting-Out & $\begin{array}{l}\text { When opting out of a maxim, the speaker } \\
\text { is unwilling to cooperate and reveal more } \\
\text { than she/ he already has. The speaker } \\
\text { chooses not to observe the maxim and } \\
\text { states an unwillingness to do so. }\end{array}$ \\
\hline & & Infringing & $\begin{array}{l}\text { When a speaker infringes a maxim, she/ } \\
\text { he unintentionally deceives or fails to } \\
\text { observe the maxim. The speaker does this } \\
\text { with no intention of generating an } \\
\text { implicature. }\end{array}$ \\
\hline & & Suspending & $\begin{array}{l}\text { When one suspends a maxim, it is } \\
\text { understood that what is said is not } \\
\text { completely true or that there are things } \\
\text { the speaker ought not to say, for example } \\
\text { taboo words. It may be due to cultural } \\
\text { differences that a speaker suspends a } \\
\text { maxim or to the nature of certain events } \\
\text { or situations. }\end{array}$ \\
\hline
\end{tabular}


This study used natural data and contained discourse features. The "live" tape-recorded events were found on YouTube entitled Miss Teen USA 2005, Miss Teen USA 2006, and Miss Teen USA 2007. The three video clips later downloaded from the website.

After the collection of these three video clips, each one of them was transcribed manually. All transcriptions were interpreted by looking at maxims. The classifications conducted had been converted into a table in order to see a clearer pattern of the answers given by all contestants from the years of 2005 until 2007.

\section{Results and discussion}

All finalists' answers had been classified according to their categories and are illustrated in the following table:

Table 2: The summary of maxims based on Miss Teen USA finalists' answers

\begin{tabular}{|c|c|l|c|c|c|}
\hline & Observance/ Non-Observance & Types & $\mathbf{2 0 0 5}$ & $\mathbf{2 0 0 6}$ & $\mathbf{2 0 0 7}$ \\
\hline \multirow{3}{*}{1} & Observance of Maxims & Quality & 5 & 5 & 4 \\
\cline { 3 - 6 } & & Quantity & 2 & 2 & 1 \\
\cline { 2 - 6 } & Relation & 3 & 5 & 4 \\
\cline { 3 - 6 } & Manner & 4 & 5 & 4 \\
\hline \multirow{2}{*}{2} & \multirow{2}{*}{ Non-Observance of Maxims } & Flouting & 5 & 3 & 3 \\
\cline { 3 - 6 } & & Infringing & - & - & 1 \\
\hline
\end{tabular}

From the table above, it can be said that, many finalists observed maxims as compared to non-observance of maxims. A majority of the contestants' answers contained all types of the observance maxims which were the maxims of quality, quantity, relation and manner. Only one contestant infringed the maxims and a few other contestants flouted the maxims.

In 2006's Miss Teen USA, Miss Montana observed all types of maxims and her answer is illustrated in the following extract:

\section{Extract 1}

Judge: "My question is, what does integrity mean to you?"

Miss Montana: "Integrity means to me someone who is driven... when you are... when you have integrity you are driven. And, you will do all that you can, and not let anything stops you to get to the goal that you are trying to achieve. That is integrity".

This response had made Miss Montana win the 2006's Miss Teen USA. Apparently, she observed all four maxims. The maxim of quantity could be seen from her information which was as informative as required. Next, the maxim of quality was identified through her answer. It was not inadequate and she had given a correct meaning as well based on her perspective. On top of that, the answer was also relevant and not in ambiguity. It was brief and did not have any unnecessary prolixity.

On the other hand, Miss West Virginia who had participated in 2005's Miss Teen USA, flouted the maxim of quantity. Her final answer can be seen in the extract below:

Extract 2

Host: "What do you spend the majority of your time thinking about?"

Miss West Virginia: "What I am going to do next? I'd never know what I'm going to do. I am a very spontaneous person so I am always mmmm... what I'm going to do the next? So, that's it. Yeah".

As illustrated in her answer, Miss West Virginia said that she was a very spontaneous person. This was not required and could be considered as additional information. Nevertheless, she observed the maxim of quality by giving a true answer about herself. She observed the maxim 
of relation as well for being relevant. Lastly, she did observe the maxim of manner by telling it in order and brief.

Apart from observing all maxims and flouting, there was a delegate from South Carolina who infringed the maxim during 2007's Miss Teen USA. Her answer is illustrated in the following extract:

\section{Extract 3}

Judge: "Recent polls have shown a fifth of Americans can't locate the US on a world map. Why do you think this is?"

Miss South Carolina: "I personally believe that U.S. Americans are unable to do so because, uh, some, uh... people out there in our nation don't have maps, and, uh, I believe that our education like such as in South Africa and, uh, Iraq everywhere like, such as and... I believe that they should, our education over here in the U.S. should help the U.S., err, uh, should help South Africa and should help Iraq and the Asian countries, so we will be able to build up our future for our..."

From the excerpt, we can conclude that, Miss South Carolina had infringed the maxims. This can be seen from her impaired response due to nervousness which made her constitutionally incapable of speaking clearly to her point.

\section{Conclusion}

When a speaker observes all maxims, it might not be that interesting to certain people. Perhaps to these people, the response will be interesting if the speaker observes some nonobservance maxims. For someone who is answering impromptu questions, it might lead to the usage of non-observance maxims. For instance, in beauty pageants, many contestants observe all four maxims. Nevertheless, when a contestant tries to pose their intelligence to judges, she sometimes flouts the maxim of quantity by giving more information than it is required. Apart from that, when a contestant is in nervousness, the possibility to infringe maxims is quite high as well. In the case of Miss Teen USA for example, even though US Americans are prominent as good public speakers but when it comes to certain conditions like answering impromptu questions, US Americans also have a high possibility to "break" maxims.

\section{References}

Grice, H. P. 1975. Logic and conversation. In P. Cole, \& J. Morgan (eds.). Studies in Syntax and Semantics III: Speech Acts. New York: Academic Press, 183-198.

Miss Teen USA 2005 Final Questions. Available at https://www.youtube.com/watch?v=eJbGQDNj_k.

Miss Teen USA 2006 Final Questions. Available at https://www.youtube.com/watch?v=8QxNawUOusk

Miss Teen USA 2007 Finalists' On-Stage Questions. Available at http://www.youtube.com/watch?v=tKXA8iTYG_A

Thomas, J. 1995. Meaning in interaction: An introduction to pragmatics. Harlow: Pearson Education. 